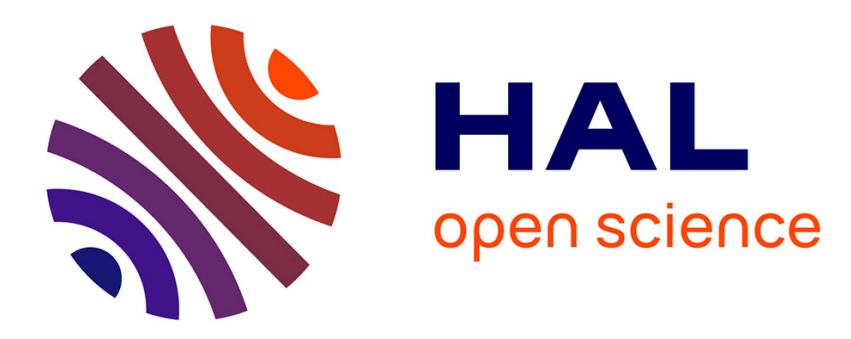

\title{
Hungary 1956: Júlia Rajk or the power of mourning Andrea Petö
}

\section{To cite this version:}

Andrea Petö. Hungary 1956: Júlia Rajk or the power of mourning. Clio. Femmes, Genre, Histoire, 2015, pp.151-163. hal-03226357

\section{HAL Id: hal-03226357 https://hal.science/hal-03226357}

Submitted on 14 May 2021

HAL is a multi-disciplinary open access archive for the deposit and dissemination of scientific research documents, whether they are published or not. The documents may come from teaching and research institutions in France or abroad, or from public or private research centers.
L'archive ouverte pluridisciplinaire HAL, est destinée au dépôt et à la diffusion de documents scientifiques de niveau recherche, publiés ou non, émanant des établissements d'enseignement et de recherche français ou étrangers, des laboratoires publics ou privés. 


\section{Hungary 1956: Júlia Rajk or the power of mourning}

A recent article by Nanette Funk on the legacy of official state socialist women's organizations raises the question of agency, and queries some recent feminist scholarship: she argues that insufficiently critical analysis of those women who collaborated with the communist power and held posts in the hegemonic communist women's organizations has obscured the lives and struggles of those who were fighting for democracy. ${ }^{1}$

This paper is an attempt to introduce the complexities of agency into a micro-study of the struggle to reclaim one's name. ${ }^{2}$ For one particular woman, the issue took on a special significance. Finding a name of her own became an important political task. When Júlia Földi (1914-1981) married László Rajk (1909-1949), leader of the Hungarian Communist Party, she took his name, and the course of her life changed irrevocably. Her marriage was an entrance ticket to a high-level leadership position in the communist women's organization (Hungarian Women's Democratic Alliance: MNDSZ). But when her husband was arrested in 1949, she was also arrested and sentenced to five years of imprisonment, for her activity within the women's organization. No other activist in Hungary paid such a price for being a politically active woman. ${ }^{3}$

Milan Kundera has characterized resistance to communism as a fight against forgetting, achieved through the power of memory. In twentieth-century Hungarian history, Júlia Rajk pleaded more eloquently than anyone else against the official versions of forgetting.

\footnotetext{
Funk 2014: 344-360.

2 Riley 1988.

3 Petö 2001, 2013.
} 
She had to fight for many years for the right to use her own name as Júlia Rajk, as well as to reclaim the name of her son and that of her husband (László Rajk). When she was released from prison, it was under a different name (Lászlóné Györki). Her son, who had been just five months old at the time of her arrest, had been placed in an orphanage and renamed István Kovács, the most common name in Hungary. She knew then that it was essential that her husband be rehabilitated, having been recognized as the victim of a Stalinist show trial in 1949. In 1955, during her own rehabilitation process, she fought fiercely for the right to use the name of Mrs László Rajk.

The life stories of women who joined the communist movement before World War Two can be told from different perspectives, depending on the degree of hindsight of the historian and the construction of a gendered political subjectivity. Since very few women actually held important positions in mainstream politics, those few tend to be described either as ruthless and cunning manipulators, or as victims who believed in the good cause (i.e., communism) but allowed themselves to be misled in practice, while being full of good intentions to promote women's rights. ${ }^{4}$

Júlia Rajk's life story should be presented differently. It is not a Bildungsroman, a story that developed out of her childhood experiences. She was born into a leftist working class family, as her father was a soldier during the short-lived Hungarian communist revolution of 1919 and was on the watch list of the police after that. She herself was a committed activist, a member of the underground communist party, and she remained so until her death in 1981. She always used her power - the power of a widow and a victim of the show trials - to achieve what she wanted: from the rehabilitation of her husband to obtaining passports for dissidents.

By examining a major turning-point in her life, the events of 1956, I aim to explore the complexities of the relations between gender and communism, and the construction of female political subjectivity.

$4 \quad$ Funk 2014. 


\section{The key to political influence: the silent "language of mourning and grief"}

"Grief is the common language of humanity,"5 ("Gallicus" during a Radio Free Europe broadcast 22 June 1956). Júlia Rajk, having mastered the language of grief, exploited this "moral capital" to contribute to the fall of the Rákosi regime in that year. The "language of grief" has first and foremost been a women's language, from Antigone to the Christian figures of the Virgin Mary and Mary Magdalene. This gave Júlia Rajk her source of inspiration, staunch materialist and communist though she was. As a wife fighting for her husband to receive an honorable burial, she was able to rise above the internal debates and divisions of Hungarian politics.

When we think of Mrs László Rajk today, perhaps the image that first springs to mind is that of the mourning wife and mother at László Rajk's reburial. The politically committed woman who frequently spoke out is forgotten. It is true that Júlia Rajk never held a position of formal or institutional power; she was merely a leading official in the women's organization (MNDSZ). Researching women's life stories always poses the methodological problem of scarcity of sources. Júlia Rajk's writings, consisting of personal letters and the transcript of a speech, have largely been lost, or else are inaccessible to researchers, being among the papers of the influential Hungarian Minister of Culture, György Aczél (1917-1991); his estate has restricted access to his archives, despite his status as a public figure. Any records of intercepted communications, a most valuable source for historians, appear to have been destroyed in the case of Júlia Rajk. None survive in the Historical Archives of Hungarian State Security: János Kádár particularly feared anything relating to the name of "Rajk", since Kádár had played an active role in the show trial which led to the execution of a man who had been his comrade and the father of his godson.

Júlia Rajk's ability to challenge the institutional sphere from a private point of view places her among prominent female figures who prepared the way for the 1956 Revolution. She was able to maneuver

5 Commentary by Gallicus, broadcast by Radio Free Europe on June 22, 1956. Reflector, No.C-339. National Széchenyi Library, Budapest. Radio Free Europe Collection 451/1083, 2. 
diplomatically between the two arenas, doing so with an unimpeachable moral authority. As the distinguished women's historian Laurel Thatcher Ulrich has put it: "well-behaved women don't make history," and certainly this applies to Júlia Rajk. Some of her contemporaries were taken aback by the outspokenness of this tall chain-smoking woman; they regarded her as rude and tactless. Júlia Rajk did not care much for social convention or for what people thought of her; she adhered to her own norms and principles. Few people in twentieth-century Hungarian history counted both Mátyás Rákosi (1892-1971) and János Kádár (1912-1989), powerful leaders of the Hungarian Communist Party, as their personal enemies. These two men had personally taken part in the judicial murder of her husband and - in the case of Kádár - in the subsequent murder of Imre Nagy (1896-1958), the Prime Minister during the 1956 revolution, the man who had spoken out in favor of her husband's rehabilitation.

Júlia Rajk had very precise ideas concerning the reburial proceedings for her husband: "Since they have already staged a show trial, they should now hold a show burial," she said to friends, as we know from oral testimony. Júlia Rajk never faltered throughout the lengthy process of preparing for the funeral, including the controversy over the various arrangements: when and where it should be held, whether to have a funeral bier, who should speak, whether the public should be allowed to attend. She told the authorities that if the public were denied access to the cemetery, she too would lay her flowers at the perimeter fence. Until the very last moment, the party leadership refused to countenance a major public burial. At Júlia Rajk's behest, the party-opposition (party members critical of the leadership) made a whole series of telephone calls in Budapest, telling people that László Rajk's widow intended to stay away from the funeral if the authorities insisted on posing conditions. In this way, within a day or so, the whole of Budapest was mobilized, and pressure was placed on the party leadership. It was then that people understood the extent of the power that lay in their hands. On 5 October 1956, twelve hours before the burial was due to begin, the party leadership finally realized the major embarrassment that would follow for it, if Mrs. Rajk stuck to her word and refused to attend the 
burial. At the last moment, therefore, they gave permission for the cemetery to be opened to the public.

During the burial itself, both sides wished to avoid a disturbance. "It is enough if they see just how many we are," said Júlia's friends, who had fresh memories of Soviet tanks on the streets of Berlin. Everyone was well aware that this was no ordinary funeral; through their attendance, people were clearly making a political statement. In the preceding 30 years, no-one could remember so many flowers labelled with the same words: "We shall not forget." Instead of a small crowd of "mobilized" party members (which the Political Committee had originally anticipated), in the end 350,000 people filed past the funeral bier and stood around the grave. Their presence was due, first and foremost, to Júlia Rajk's determined campaign. Photographs of the burial were published around the world. The words at the graveside were pronounced by men, but it was the image of the widow with her young son that ultimately defined the iconic memory of the event. The photograph, which has been reproduced in every textbook since 1989, has shaped public memory of her as a wife - but at the same time it has obscured and sidelined her successful political campaigns.

Preparations for the reburial increased the confidence of the future leaders of the Hungarian Revolution, who saw how it was possible, using the telephone, to mobilize hundreds of thousands of people for a "cause." The implacability of Júlia Rajk and her insistence on the widest publicity for her husband's reburial on 6 October 1956 rendered the event a psychological dress rehearsal for the Revolution. She achieved this by courageously using the "language of grief" in the public sphere, ignoring the required rhetoric of the communist movement. None of the other wives of the regime's victims (Pálffy, Szőnyi, Szalai) who also stood at the coffins of their executed husbands on that day, chose this course of action, and none of them was able to replicate her political successes.

\section{Contacts and networks}

It was back in 1954 that her campaign had begun. Having spent five years in prison as Rajk's wife, she was released in that year. Her life then took on a new purpose, and she became a political activist, 
determined to make use of her political and moral power as the exprisoner wife of an unjustly executed communist Minister of the Interior. Her single goal was to achieve her husband's rehabilitation. This apparently individual aim had vast collective and political implications, since in a broader sense it implied the rehabilitation of the thousands of people persecuted by the Rákosi regime, thus effectively calling into question the regime's very legitimacy.

In her battle for her husband's memory and for her own name, Júlia Rajk was forced to fight on several fronts. First, on account of the perceived harshness of her husband's policies as Minister of Interior, she had to deal with the hostility of those who had opposed him within the party. Equally hostile to her were anti-communist exiles in the West, who struggled to understand the "emotional myths" that were now arising around László Rajk in Hungary, making him a "good communist". Meanwhile, the old party leaders, former close party comrades of Rajk, publicly called Júlia Rajk a traitor to the workers' movement. In spite of these attacks from both sides, she did not give up. She was determined to have her husband properly buried and to restore his name. This aim brought her into close contact with the newly emerging group of reformist communists.

In the summer of 1956, a political circle began to form around Imre Nagy. Júlia Rajk became part of this group, which often came together in the Kis Lugas restaurant on Szilágyi Erzsébet Avenue in Budapest. During research for my biography of Julia Rajk, I interviewed participants at these meetings (now all dead) who were bound together by unbreakable bonds forged during their imprisonment. They told me that to confound the state security eavesdroppers, they would sit at tables in the open air with music playing in the background. They could also meet at tea-parties they arranged for their children. Júlia Rajk was present at almost all the informal discussions that preceded the 1956 Revolution, including the meeting held on Orsó Street on 6 June 1956, which included a celebration of Imre Nagy's sixtieth birthday. Although she was aware of the monitoring of her conversations, none of the intercepts appear to have survived at the Historical Archives of Hungarian State Security. But it is clear that such informal meetings with friends, at 
parties and on excursions, provided the fabric for a counter-society working against the dominant authorities.

\section{The "partisan debate" in the Petôfi Circle: creating a public language}

By campaigning for he husband's public reburial from 1954 on, Júlia Rajk helped establish a political link between the Imre Nagy group and the Petôfi Circle of reformist intellectuals. Organized by the Circle, the "partisan debate" (18 June 1956) was Júlia Rajk's first appearance in public since 1949. The significance of her speech was huge, as it created the linguistic framework for loyal communists nevertheless to criticize the Rákosi regime in a legitimate fashion.

The so-called partisan debate was held at the Central Officers Mess of the Hungarian National Army Division on Váci Street in Budapest. Unlike previous debating meetings held by the Petőfi Circle, on this occasion formerly imprisoned communists stood up to tell how, despite their imprisonment, they still believed in communism. What they did want, however, were radical changes in the policies and composition of the party leadership. For members of the public attending the meeting, the most interesting aspect was, as one of the participants said, to see "how the communists lambast each other in debate." The meeting, which lasted until dawn, had an important message: the communists were now proclaiming the need to face up to the past - something they had previously denounced as a "right-wing reactionary" demand.

The words spoken by Júlia Rajk at the meeting were recorded; they deserve our special attention, as she rarely made public speeches. ${ }^{6}$ It is clear even from the edited, published version, that it was not a prepared speech. Her words were spoken spontaneously and from the heart. When she appeared on the rostrum, she was applauded for around ten minutes, as she was a symbolic figure for victims of communism. And at the end of her speech, "the hall resounded with approval." She spoke in a clear and considered way, posing many rhetorical questions. The effectiveness of the speech

6 Pető 2001: 246-250. 
was due to her credibility as one who had suffered at the hands of the regime. Once again, she used the "language of grief" in a masterly fashion. She compared and contrasted the prisons of the Horthy regime with those run by the communist authorities, concluding that prisoners had received better treatment in the former. Rather than make statements, she posed the following questions:

How is it possible that the reactionaries saw what the comrades failed to see? Where is the error in the system that allowed [people] not only to make mistakes, but also to commit grave crimes? Where is this error, which still exists? I must say that the people who now want to rehabilitate [the victims] are the same ones who sentenced them, who murdered them, and who sent them to the gallows.

Júlia Rajk then analysed the anomalies of the process of rehabilitation, in particular the resolution on rehabilitation passed by the communist party in November 1955, which was both limited and limiting. With great conviction, she insisted that László Rajk had been a good communist, one who was worthy of being chosen as a model for young communists.

I feel that the Rajk issue constitutes a part of the process whereby they have destroyed this country economically, politically and morally, whereby they could even trample on the backbone of someone earning 800 forints who feared for his job... Relying on the Hungarian people, we - all of us, the old underground communists and the new intellectuals - must now reinstate Leninist norms. They forced the old comrades out, and this all started with the trial of Rajk in 1949.

Her message was clear: the old comrades had been suppressed by newcomers who had caused much damage to the party. Her mission was therefore to accomplish László Rajk's rehabilitation, because this would allow for a return to the historic communist path, which had broad national support. Moreover, the spirit of the Twentieth Congress of the Communist Party of the Soviet Union needed to be applied in Hungary, and this would necessarily result in leadership changes.

The speech aroused people's emotions, but it also presented a clear political program. The personal suffering of Júlia Rajk added weight to her words. Her rhetoric was again based on personal experience and had emotional weight. She received a standing ovation from the 2000 people in attendance. With this speech, Júlia Rajk 
became an iconic figure. Acting in her own right, she had made plain her claim to a public role - in order to achieve her husband's rehabilitation. This distinguished her from the other widows and made her a public political figure.

\section{A new form of charity: Júlia Rajk and the National Association of People's Colleges (NÉKOSZ)}

In the summer of 1956, people's efforts to establish a new Hungary intensified. Graduates of the people's colleges were among those who exhibited the greatest commitment to this program. The people's colleges had been established in the 1930s, as part of an initiative to improve society by training talented people to become cadres. After 1945, the Communist Party consciously supported the movement with a view to achieving the replacement of the old elite. As an ironfisted interior minister, László Rajk had been one of the leading supporters of the people's colleges, and his wife had become the patron of the only college run exclusively for women, the Zrinyi Ilona People's College. In 1949, the NÉKOSZ (National Association of People's Colleges) was disbanded in the aftermath of Rajk's detention and as part of the growth of the personality cult around Rákosi. Subsequently, many of its former members were imprisoned.

The members of NÉKOSZ, with their broad social network and excellent skills and talents, had been bitterly disappointed. Indeed, László Rajk's martyrdom embodied for many of them the loss of their own dreams. Júlia Rajk liked to speak about the people's colleges, even claiming that László Rajk would have been delighted to have been a member. She announced in the summer of 1956 that she wished to donate the sum she had received from the state for the purpose of rehabilitation (200,000 Forints) to the people's colleges which should reopened. Evidently, her intention in making this act of personal charity was to demonstrate social responsibility and to set a moral example. It was an unexpected action from someone who was fighting against bourgeois values and structures. 


\section{During the revolution: the power of conversation}

As we know from Géza Losonczy’s “confession,” Júlia Rajk, with her authenticity and her moral capital, was a potent force in establishing a new socialist party on 23 October 1956. Her name even features among those proposed by Imre Nagy for membership of the central leadership group. On the outbreak of the revolution, she was vacationing in Berlin, and immediately departed for Hungary, arriving home after a horrendous journey on 2 November. She at once sought to get involved in the revolutionary events. On 3 November, the newspaper Magyar Honvéd (Hungarian Soldier) published the interview that was Júlia Rajk's sole formal contribution to the revolution. All the revolutionary leaders were her former comrades-in-arms and personal friends. It was quite natural, therefore, for her to appear at the offices of Géza Losonczy, Minister of Information in the Nagy government. That same day, 3 November 1956, a day before the Soviet invasion, representatives of the new left (Lajos Fehér, Mrs Kádár, Mrs Rajk, Újhelyi, Szántó, Boldizsár, and Gimes) met at the Parliament building, where they discussed the likely course of events. During the Revolution, which lasted only a few days, Júlia Rajk did what she liked doing best, and had the greatest talent for: talking to people. Despite the rapid pace of events, the Revolution had begun to set up institutions such as political parties and workers' councils. Júlia Rajk, like the other women in the communist nomenclatura, received a place in these structures only because her exceptional status. In the documents produced about the events, she is listed as one of the participants, but without any mention of what she had actually done.

\section{After the 1956 revolution: the power of the institutionalization of informality}

Following the Soviet invasion of Hungary, at 9 a.m. on 4 November 1956, Júlia Rajk and her son were at the Yugoslav Embassy with other members of Imre Nagy's group. From there they were taken with the others to Romania. As a prisoner in Snagov, Romania, Júlia Rajk read with great interest a newspaper report about the women's demonstration held on 4 December 1956. As we know from the 
memoirs of Vera Bácskai, the widow of Gabor Tanczos, Júlia Rajk noted that it was perhaps just as well she was in Snagov, for if she had stayed in Budapest, she would have been leading the demonstrators as the Soviet tanks opened fire. In actual fact, the Soviet tanks did not fire at the women demonstrators on that occasion. Owing to press censorship, Júlia Rajk could not know that the power of women's resistance had protected the demonstrators - as it had done in earlier stages of Júlia Rajk's life, and would do so again subsequently. When the male members of Imre Nagy's group were taken back to Hungary in 1958, an opportunity emerged in Snagov for an informal group, whose leader and spokeswoman Júlia Rajk became. She created her own school - "Júlia's school" - which kept the vulnerable and increasingly apathetic prisoners busy and helped their children, after their return home, to fit back into society.

This case study of Júlia Rajk illustrates that her early membership of the underground communist movement in her own right, did not help her to achieve any position of power in the newly-built communist Hungary. It was only the fact that she was married to a powerful man that led her to be a prominent figure in the communist women's organization. Thereafter, as the victim of a show trial, she changed her political rhetoric, but not her beliefs: she used the women's "language of mourning" to establish an informal power position, which enabled her to become, however briefly, an actor in the field of formal politics.

\section{Bibliography}

FUNK, Nanette. 2014. A very tangled knot: official state socialist women's organizations, women's agency and feminism in Eastern European state socialism. European Journal of Women's Studies 4: 344-360.

Petó, Andrea. 2001. Rajk Júlia, Budapest: Balassi [in German: Geschlecht, Politik und Stalinismus in Ungarn. Eine Biographie von Júlia Rajk. Herne: Gabriele Schäfer Verlag, 2007. In Bulgarian: Julia Rajk. Sofia: Altera, 2010].

PETÓ, Andrea. 2013. A missing piece: how Hungarian women in the communist nomenclatura are not remembering. In Eastern Europe: women in transition, ed. Irena Gridzinska Gross and Andrzej TyMowski, 145-155. Frankfurt: Peter Lang.

RAINER, M. Janos. 2009. Imre Nagy: a Biography. London: Tauris.

RILEY, Denise. 1988. Am I That Name? Feminism and the category of 'women' in history. London: Macmillan. 